\title{
Quaderni
}

QUADERN I Communication, technologies, pouvoir

\section{Futurologie et transitologie : les think tanks face à la "société de l'information"}

\section{David Forest}

\section{(2) OpenEdition}

\section{Journals}

\section{Édition électronique}

URL : http://journals.openedition.org/quaderni/706

DOI : 10.4000/quaderni.706

ISSN : 2105-2956

\section{Éditeur}

Les éditions de la Maison des sciences de l'Homme

\section{Édition imprimée}

Date de publication : 5 octobre 2009

Pagination : 29-38

\section{Référence électronique}

David Forest, «Futurologie et transitologie : les think tanks face à la "société de l'information" », Quaderni [En ligne], 70 | Automne 2009, mis en ligne le 05 octobre 2011, consulté le 02 mai 2019. URL : http://journals.openedition.org/quaderni/706 ; DOI : 10.4000/quaderni.706

Ce document a été généré automatiquement le 2 mai 2019.

Tous droits réservés 


\title{
Futurologie et transitologie : les think tanks face à la "société de l'information"
}

\author{
David Forest
}

\section{NOTE DE L'ÉDITEUR}

L'auteur n'a pas donné son accord pour la diffusion électronique de son article.

\section{RÉSUMÉS}

Liés à l'étude des stratégies militaires, les think thanks jouent rapidement un rôle important dans le façonne-ment, l'évolution et la diffusion des méthodes de la futurologie. Ils se sont également investis de la mission, d'une part, de " penser » la société "post-industrielle » devenue "société de $1^{1}$ information » et, d'autre part, d'accompagner la transition d'un type de société à un autre sur fond de «fin des idéologies » et de révolution technique permanente.

In relation with military strategies, think tanks are quickly playing an important role regarding the shaping, evolution and diffusion of the futurology methodology. They have also taken part in the mission, on one hand, to think the "post-industrial" society which became the "information" society, and on the other hand, they have participated to the transition of one type of society to the other in the context of the end of ideologies and permanent technical revolution. 
AUTEUR

DAVID FOREST

LAS/LARES Université Rennes 2 